\title{
Barriers to treated bednet usage in Timor-Leste: an explaratory study
}

\author{
AA Lover ${ }^{1 *}$, BA Sutton ${ }^{2}$, AJ Asy ${ }^{2}$ \\ From Institut Pasteur International Network Annual Scientific Meeting \\ Hong Kong. 22-23 November 2010
}

Timor-Leste has some of the highest malaria rates in Asia- the WHO reports that $100 \%$ of the population is at year-round risk. A 2007 survey estimated that ITN usage ( 30 day) was only $28.8 \%$ in the under -5 population, and the MDG report also highlights several large disparities in ITN usage across the population- $69.6 \%$ urban and $45.5 \%$ rural; and $54 \%$ of males and only $46 \%$ of females, according to the Timor-Leste National Statistics Directorate (2007) and The Millennium Development Goals, Timor-Leste (2009). There have been many qualitative surveys about attitudes towards ITN usage in Sub-Saharan Africa, but far fewer from SE Asia [1].

To more fully understand the barriers to usage in Timor-Leste, a series of nine focus group discussions were organized in July, 2010. These discussions covered a range of peri-urban and rural areas, and were separated by sex, to allow exploration of intra-household decision making processes. A total of 53 women and 46 men participated, all of whom were heads of households or decision makers, and owned at least one bednet. A range of social, logistic and economic barriers emerged from these discussions, and could facilitate the creation of more targeted behavior-change materials.

\section{Author details}

'Department of Epidemiology and Public Health, National University of Singapore, Singapore 117597. ${ }^{2}$ Timor-Leste Asistencia Integradu Saúde (TAIS) (Timor-Leste Integrated Health Assistance), Timor-Leste.

Published: 10 January 2011

\section{Reference}

1. Morrow M, Quy A, Nguyen QA, et al: Pathways to malaria persistence in remote central Vietnam: a mixed-method study of health care and the community. BMC Public Health 2009, 9:85.

'Department of Epidemiology and Public Health, National University of Singapore, Singapore 117597

Full list of author information is available at the end of the article
doi:10.1186/1753-6561-5-S1-P16

Cite this article as: Lover et al:: Barriers to treated bednet usage in Timor-Leste: an explaratory study. BMC Proceedings 2011 5(Suppl 1):P16.
Submit your next manuscript to BioMed Central and take full advantage of:

- Convenient online submission

- Thorough peer review

- No space constraints or color figure charges

- Immediate publication on acceptance

- Inclusion in PubMed, CAS, Scopus and Google Scholar

- Research which is freely available for redistribution

\section{Biomed Central}

\section{Biomed Central}

